
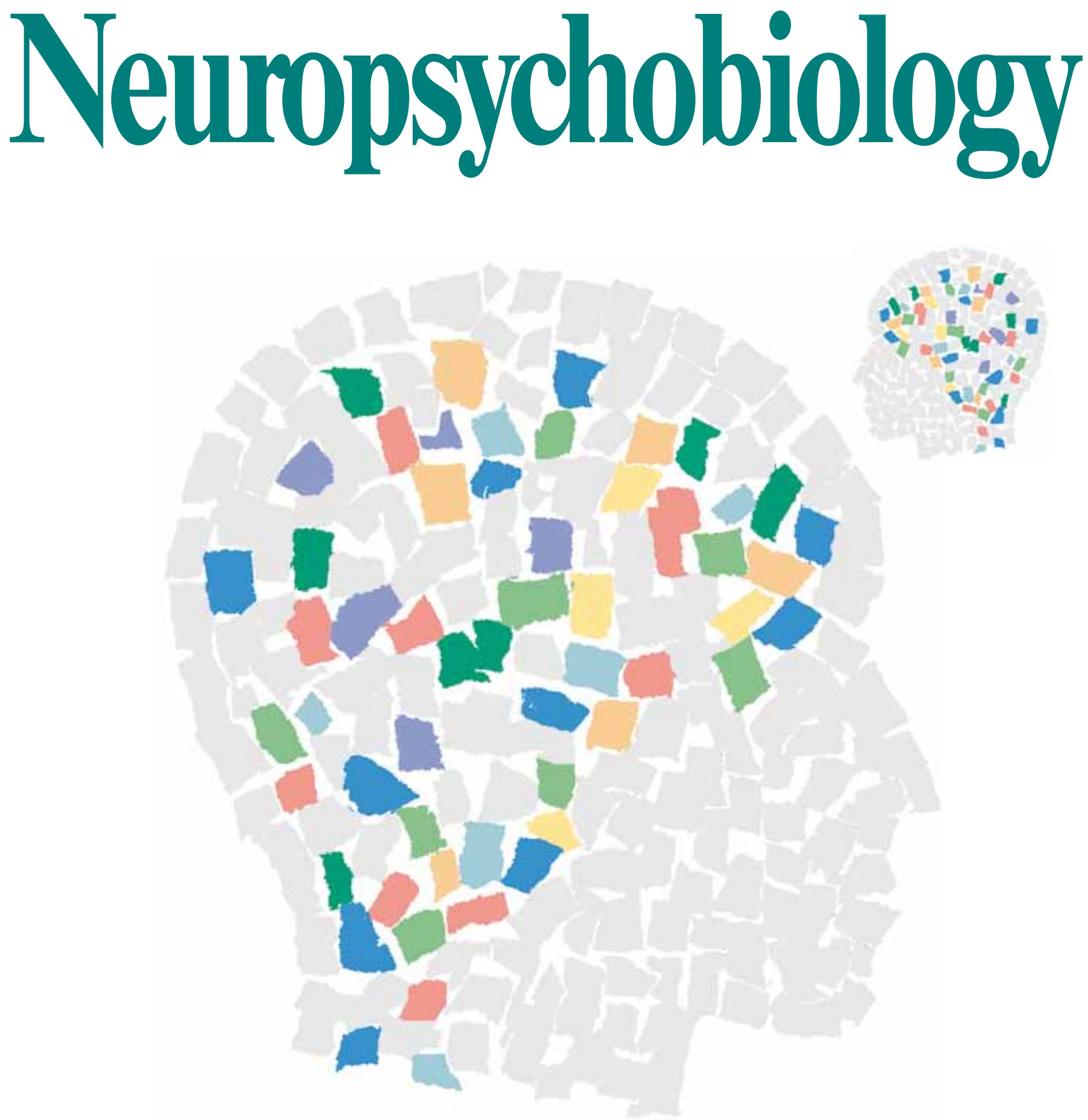

S. Karger

Medical and Scientific Publishers 


\title{
Garger
}

\section{Stimulating reading} in and around the world of medicine

The biomedical themes of the Karger Gazette are topical, urgent, exciting. Its articles, written by experts from all over the world, provide a wide audience with the basic issues, new findings and controversies in a lively and readable style. Alongside invited contributions, each number carries attractively presented support material, such as informative graphics, historical summaries, interviews, or portraits of individuals and institutions. The Karger Gazette is published in newspaper format and appears once a year.

And what's more - it's free!

To see behind the cover, please write or e-mail us, and we'll start your subscription with the latest issue. www.karger.com/gazette

\section{Current issue:}

\section{The Aging Issue}

Read about the causes of the aging process, why aging stops in later adult life, the quiet epidemic of Alzheimer's Disease, internet use by seniors, and more.

\author{
S. Karger AG \\ Karger Gazette \\ Allschwilerstrasse 10 \\ CH-4009 Basel (Switzerland) \\ E-Mail gazette@karger.com \\ www.karger.com
}

\section{KARGER}


International Journal of Experimental and Clinical Research in Biological Psychiatry, Pharmacopsychiatry, Biological Psychology/Pharmacopsychology and Pharmacoelectroencephalography

Founded 1975 by J. Mendlewicz (Brussels).

Since 1983 integrating 'International Pharmacopsychiatry',

founded 1968 by F.A. Freyhan (New York), N. Petrilowitsch (Mainz), P. Pichot (Paris)

Section Editor Pharmacopsychiatry and Associate Editor 1990-2006 B. Saletu (Vienna)

Founder, Section Editor Biological Psychiatry and Associate Editor 1975-2007 J. Mendlewicz (Brussels)

\section{Editor-in-Chief}

W. Strik, Bern

\section{Administrative Editor}

D. Krneta Messmer, Bern

\section{Associate Editors}

T. Kinoshita, Osaka

P. Netter, Giessen

D.F. Salisbury, Pittsburgh, Pa.

A. Serretti, Bologna

\section{Editorial Board}

R. Calati, Bologna

A. Drago, Naples

G. Erdmann, Berlin

A. Fischer, Göttingen

J.M. Ford, San Francisco, Calif.

S. Galderisi, Naples

M. Hatzinger, Solothurn

K. Hirata, Mibu

M. Kato, Osaka

J. Kindler, Bern

T. Koenig, Bern

D. Lehmann, Zürich

M. Maes, Geelong, Vic.

L. Mandelli, Bologna

P. Monteleone, Naples

G. Okugawa, Osaka

G.N. Papadimitriou, Athens

M. Popoli, Milano

M. Reuter, Bonn

G. Ruigt, Oss

J.K. Rybakowski, Poznan

F. Rybakowski, Warzaw/Poznan

F. Schneider, Aachen

R. Schwarting, Marburg

D. Souery, Brussels

A. Steiger, Munich

S. Walther, Bern

K. Watanabe, Tokyo

P. Willner, Swansea

M. Yoshimura, Osaka
Printed in Switzerland on acid-free and non-aging paper (ISO 9706) by Reinhardt Druck, Basel 


\section{Neuropsychobiology}

\section{Submission}

Only papers written in English are considered and should be submitted using the online submission website at: www.karger.com/nps. Should you experience any problems with your submission, please contact

Prof. W. Strik

University Hospital of Psychiatry

Waldau

CH-3000 Bern 60 (Switzerland)

E-Mail: neuropsychobiology@puk.unibe.ch

\section{Conditions}

All manuscripts are subject to editorial review. Manuscripts are received with the explicit understanding that they are not under simultaneous consideration by any other publication. Submission of an article for publication implies transfer of the copyright from the author to the publisher upon acceptance. Accepted papers become the permanent property of 'Neuropsychobiology' and may not be reproduced by any means, in whole or in part, without the written consent of the publisher. It is the author's responsibility to obtain permission to reproduce illustrations, tables, etc. from other publications.

\section{Arrangement}

Title page: The first page of each paper should indicate the title, the authors' names, the institute where the work was conducted, and a short title for use as running head.

Full address: The exact postal address of the corresponding author complete with postal code must be given at the bottom of the title page. Please also supply phone and fax numbers, as well as e-mail address.

Key words: For indexing purposes, a list of 3-10 key words in English is essential.

Abstract: Each paper needs an abstract in 4 paragraphs and not exceeding 250 words.

Footnotes: Avoid footnotes.

Tables and illustrations: Tables and illustrations (both numbered in Arabic numerals) should be prepared on separate pages. Tables require a heading and figures a legend, also prepared on a separate page. For the reproduction of illustrations, only good drawings and original photographs can be accepted; negatives or photocopies cannot be used. Due to technical reasons, figures with a screen background should not be submitted. When possible, group several illustrations in one block for reproduction (max. size $180 \times$ $223 \mathrm{~mm}$ ) or provide crop marks. Electronically submitted $\mathrm{b} / \mathrm{w}$ half-tone and color illustrations must have a final resolution of $300 \mathrm{dpi}$ after scaling, line drawings one of $800-1,200 \mathrm{dpi}$

\section{Color Illustrations}

Online edition: Color illustrations are reproduced free of charge. In the print version, the illustrations are reproduced in black and white. Please avoid referring to the colors in the text and figure legends. Print edition: Up to 6 color illustrations per page can be integrated within the text at CHF 800.- per page.

\section{References}

In the text identify references by Arabic numerals [in square brackets]. Material submitted for publication but not yet accepted should be noted as 'unpublished data' and not be included in the reference list. The list of references should include only those publications which are cited in the text. Do not alphabetize; number references in the order in which they are first mentioned in the text. The surnames of the authors followed by initials should be given. There should be no punctuation other than a comma to separate the authors. Preferably, please cite all authors. Abbreviate journal names according to the Index Medicus system. Also see International Committee of Medical Journal Editors: Uniform requirements for manuscripts submitted to biomedical journals (www. icmje.org)

\section{Examples}

(a) Papers published in periodicals: Chatel J-M, Bernard H, Orson FM: Isolation and characterization of two complete Ara h 2 isoforms cDNA. Int Arch Allergy Immunol 2003;131:14-18.

(b) Papers published only with DOI numbers:

Theoharides TC, Boucher W, Spear K: Serum interleukin-6 reflects disease severity and osteoporosis in mastocytosis patients. Int Arch Allergy Immunol DOI: $10.1159 / 000063858$.

(c) Monographs: Matthews DE, Farewell VT: Using and Understanding Medical Statistics, ed 3, revised. Basel, Karger, 1996.

(d) Edited books: DuBois RN: Cyclooxygenase-2 and colorectal cancer; in Dannenberg AJ, Dubois RN (eds): COX-2. Prog Exp Tum Res. Basel, Karger, 2003, vol 37, pp 124-137.

Reference Management Software: Use of EndNote is recommended for easy management and formatting of citations and reference lists.

\section{Digital Object Identifier (DOI)}

S. Karger Publishers supports DOIs as unique identifiers for articles. A DOI number will be printed on the title page of each article. DOIs can be useful in the future for identifying and citing articles published online without volume or issue information. More information can be found at www.doi.org.

\section{Supplementary Material}

Supplementary material is restricted to additional data that are not necessary for the scientific integrity and conclusions of the paper. Please note that all supplementary files will undergo editorial review and should be submitted together with the original manuscript. The Editors reserve the right to limit the scope and length of the supplementary material. Supplementary material must meet production quality standards for Web publication without the need for any modification or editing. In general, supplementary files should not exceed $10 \mathrm{MB}$ in size. All figures and tables should have titles and legends and all files should be supplied separately and named clearly. Acceptable files and formats are: Word or PDF files, Excel spreadsheets (only if the data cannot be converted properly to a PDF file), and video files (.mov, .avi, .mpeg).

\section{Author's Choice ${ }^{\mathrm{TM}}$}

Karger's Author's Choice ${ }^{\mathrm{TM}}$ service broadens the reach of your article and gives all users worldwide free and full access for reading, downloading and printing at www.karger.com. The option is available for a onetime fee of CHF 3000.-, which is a permissible cost in grant allocation. More information can be found at www.karger.com/authors_choice.

\section{NIH-Funded Research}

The U.S. National Institutes of Health (NIH) mandates under the NIH Public Access Policy that final, peer-reviewed manuscripts appear in its digital database within 12 months of the official publication date. As a service to authors, Karger submits the final version of your article on your behalf to PubMed Central. For those selecting our premium Author's Choice $^{\mathrm{TM}}$ service, we will send your article immediately upon publishing, accelerating the accessibility of your work without the usual embargo. More details on NIH's Public Access Policy is available at http:// publicaccess.nih.gov/FAQ.htm\#a1

\section{Self-Archiving}

Karger permits authors to archive their pre-prints (i.e. pre-refereeing) or post-prints (i.e. final draft post-refereeing) on their personal or institution's servers, provided the following conditions are met: Articles may not be used for commercial purposes, must be linked to the publisher's version, and must acknowledge the publisher's copyright. Authors selecting Karger's Author's Choice ${ }^{\mathrm{TM}}$ feature, however, are also permitted to archive the final, published version of their article, which includes copyediting and design improvements as well as citation links.

\section{Page Charges}

There are no page charges for papers of 5 or fewer printed pages (including tables, illustrations and references). Each additional complete or partial page is charged to the author at CHF 325.-. The allotted size of a paper is equal to approx. 15 manuscript pages (including tables, illustrations and references).

\section{Proofs}

Unless indicated otherwise, proofs are sent to the first-named author and should be returned with the least possible delay. Alterations made in proofs, other than the correction of printer's errors, are charged to the author.

\section{Reprints}

Order forms and a price list are sent with the proofs. Orders submitted after the issue is printed are subject to considerably higher prices.

\section{KARGER}

Fax +41 613061234 E-Mail karger@karger.com www.karger.com

\section{(C) 2013 S. Karger AG, Basel}




\section{Neuropsychobiology}

ISSN Print Edition: 0302-282X

ISSN Online Edition: 1423-0224

Journal Homepage: www.karger.com/nps

Publication Data: 'Neuropsychobiology' is published 8 times a year. Volumes 67 and 68, each with 4 issues, appear in 2013

Copyright: (c) 2013 S. Karger AG, Basel (Switzerland) All rights reserved. No part of this publication may be translated into other languages, reproduced or utilized in any form or by any means, electronic or mechanical including photocopying, recording, microcopying, or by any information storage and retrieval system, without permission in writing from the publisher or, in the case of photocopying, direct payment of a specified fee to the Copyright Clearance Center.

Disclaimer: The statements, opinions and data contained in this publication are solely those of the individual authors and contributors and not of the publisher and the editor(s). The appearance of advertisements in the journal is not a warranty, endorsement, or approval of the products or services advertised or of their effectiveness, quality or safety. The publisher and the editor(s) disclaim responsibility for any injury to persons or property resulting from any ideas, methods, instructions or products referred to in the content or advertisements.
Subscription Rates: Subscriptions run for a full calendar year. Prices are given per year. Personal subscription:

Print or Online

CHF 1022.-

EUR 824.-

USD 1012.00

Print+Online combined CHF 1118.-

EUR 902.-

USD 1108.00

postage and handling (added to print and print+online)

CHF 57.60 Europe, CHF 83.20 Overseas

EUR 44.80

USD 76.80

Institutional subscription:

Print or Online

Print+Online combined

CHF 2920.-

EUR 2354.-

CHF 3212.

USD 2892.00

postage and handling (added to print and print+online)

CHF 72.- Europe, CHF 104.- Overseas

EUR 56.-

USD 96.00

Airmail surcharge: CHF 70.- / USD 66.00

Discount subscription prices:

- International Pharmaco-EEG Society (IPEG)

- American Psychiatric Association (APA)

- Association of European Psychiatrists (AEP)

- International Society of Biological Psychiatry
Back Volumes and Single Issues: Information on availability and prices of single print issues and print or electronic back volumes can be obtained from Customer Service at service@karger.ch.

Bibliographic Indices: This journal is regularly listed in bibliographic services, including Current Contents ${ }^{\circledR}$ and PubMed/MEDLINE.

Photocopying: This journal has been registered with the Copyright Clearance Center (CCC), as indicated by the code appearing on the first page of each article. For readers in the US, this code signals consent for copying of articles for personal or internal use, or for the personal or internal use of specific clients, provided that the stated fee is paid per copy directly to

Copyright Clearance Center Inc.

222 Rosewood Drive

Danvers, MA 01923 (USA)

A copy of the first page of the article must accompany payment. Consent does not extend to copying for general distribution, for promotion, for creating new works, or for resale. In these cases, specific written permission must be obtained from the copyright owner,

S. Karger AG, P.O. Box

CH-4009 Basel (Switzerland).
Subscription Orders:

Orders can be placed at agencies, bookstores, directly with the Publisher

\section{S. Karger AG}

Medical and Scientific Publishers

P.O. Box

CH-4009 Basel

Switzerland

(for courier services only:

Allschwilerstrasse 10

CH-4055 Basel)

: +416130611 11

f: +41613061234

e: karger@karger.com

w: www.karger.com or further Karger offices

or representatives:

Germany

S. Karger GmbH

Postfach

79095 Freiburg

Deutschland

(Hausadresse: Wilhelmstrasse 20A

79098 Freiburg)

$\mathrm{t}: \quad+49761452070$

$\mathrm{f:} \quad+497614520714$

e: information@karger.de

w: www.karger.de

Japan

Karger Japan, Inc.

Shiba Daimon Asahi Bldg. 2F

1-2-23 Shiba Daimon

Minato-ku

Tokyo 105-0012

Japan

t: +81364356242

f: +81364356244

e: publisher@karger.jp

w: www.karger.jp
USA

S. Karger Publishers, Inc.

26 West Avon Road

P.O. Box 529

Unionville, CT 06085

USA

Toll free: +18008285479

t: +18606757834

$\mathrm{f}: \quad+18606757302$

e: karger@snet.net

France

Librairie Médi-Sciences Sar

36, bd de Latour-Maubourg

75007 Paris

France

$\mathrm{t}:+33(0) 145514258$

f: $+33(0) 145560780$

e: librairie@medi-sciences.fr

w: www.medi-sciences.fr
South East Asia, China and Taiwan

Karger Regional Office (Malaysia)

CEO Suite Kuala Lumpur

Quill 7, 27th Floor

Jalan Stesen Sentral 5

KL Sentral

Kuala Lumpur 50470

Malaysia

t: +60327766803

f: +60327766999

e: service@karger.cn; r.chew@karger.cn

Karger China

10th Floor, Twin Towers (East)

B12 Jianguomenwai Avenue

Beijing 100022

$\mathrm{t}:+861051235033$

f: +861051235122

e: service@karger.cn; r.chew@karger.cn

w: www.karger.cn

India, Bangladesh, Sri Lanka

Medscience India

Plot No. 17, Yusuf Sarai Market

B.L. Glass Building, 2nd Floor

Sri Aurobindo Marg

New Delhi 110016

India

t: +911146029633

f: +911146029634

c: +919891052128

e: medsci.india@gmail.com

Change of Address:

Both old and new address should be sent

to the subscription source.

\section{KARGER}

Fax +41 613061234

E-Mail karger@karger.com

www.karger.com
(C) 2013 S. Karger AG, Basel

The Journal Home Page is available at:

www.karger.com/nps 
क 3rd International Congress on

จ Neurobiology,

Psychopharmacology

U \& Treatment Guidance

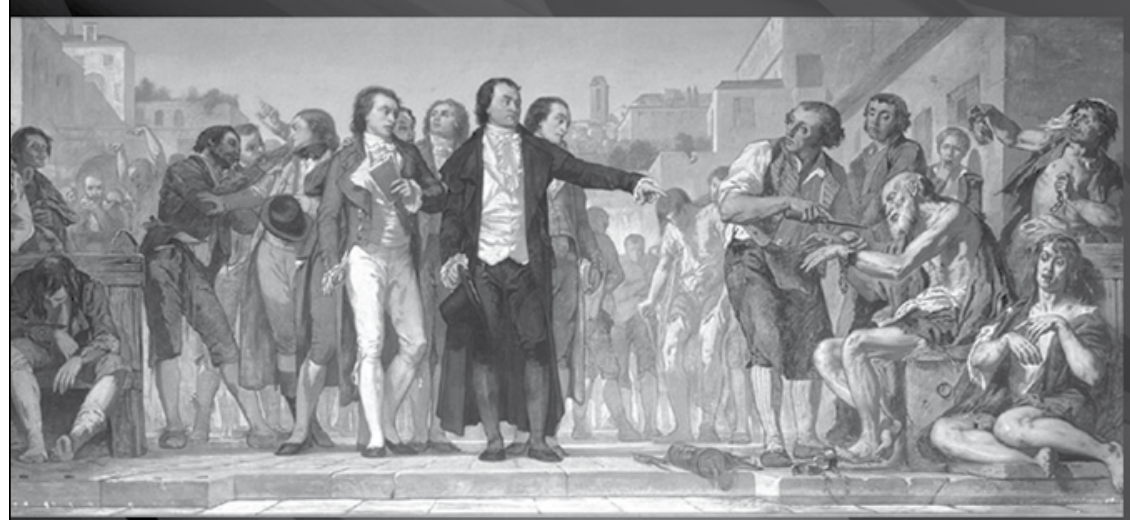

Will be accredited with CME credits by UEMS/EACCME
May $30^{\text {th }}-$ June $2^{\text {nd }} 2013$

Thessaloniki Greece

www.psychiatry.gr

INTERNATIONAL SOCIETY OF NEUROBIOLOGY \& P SYCHOPHARMACOLOGY

(P) World Psychiatric Association

Under the auspises of:

(A) School of Medicine

2. Aristotle University of Thessaloniki, Greece

⿶. Hellenic Psychiatric Association

(W) Psychiatric Association

for Eastern Europe and the Balkans

xy- World Association for Social Psychiatry

(vEPA) European Psychiatric Association

A globab Buents Head office Thessaloniki: 50A Stadiou Str. 55535 Pilea, Thessaloniki, Greece, Tel: $+302310247743,+302310247734$, Fax: +30 2310247746, E-mail: info@globalevents.gr www.globalevents.gr Branch office Athens: 6 Palaiologou Mpenizelou Str., 10556 Plaka, Athens, Greece, Tel: +30 210 3250260, E-mail: athens@globalevents.gr

\section{Society of Biological Psychiatry 68th Annual Scientific Convention}

May 16-18, 2012 | Hilton Union Square Hotel | San Francisco, California

Neuroplasticity and the Changing Brain: Development, Pathobiology, and Therapeutics

Save the Date 


\section{Contents}

See the journal website for contents

KARGER Basel $\bullet$ Freiburg $\cdot$ Paris $\bullet$ London $\bullet$ New York $\cdot$ New Delhi $•$ Bangkok Beijing $\cdot$ Tokyo $\cdot$ Kuala Lumpur $\cdot$ Singapore $\bullet$ Sydney 


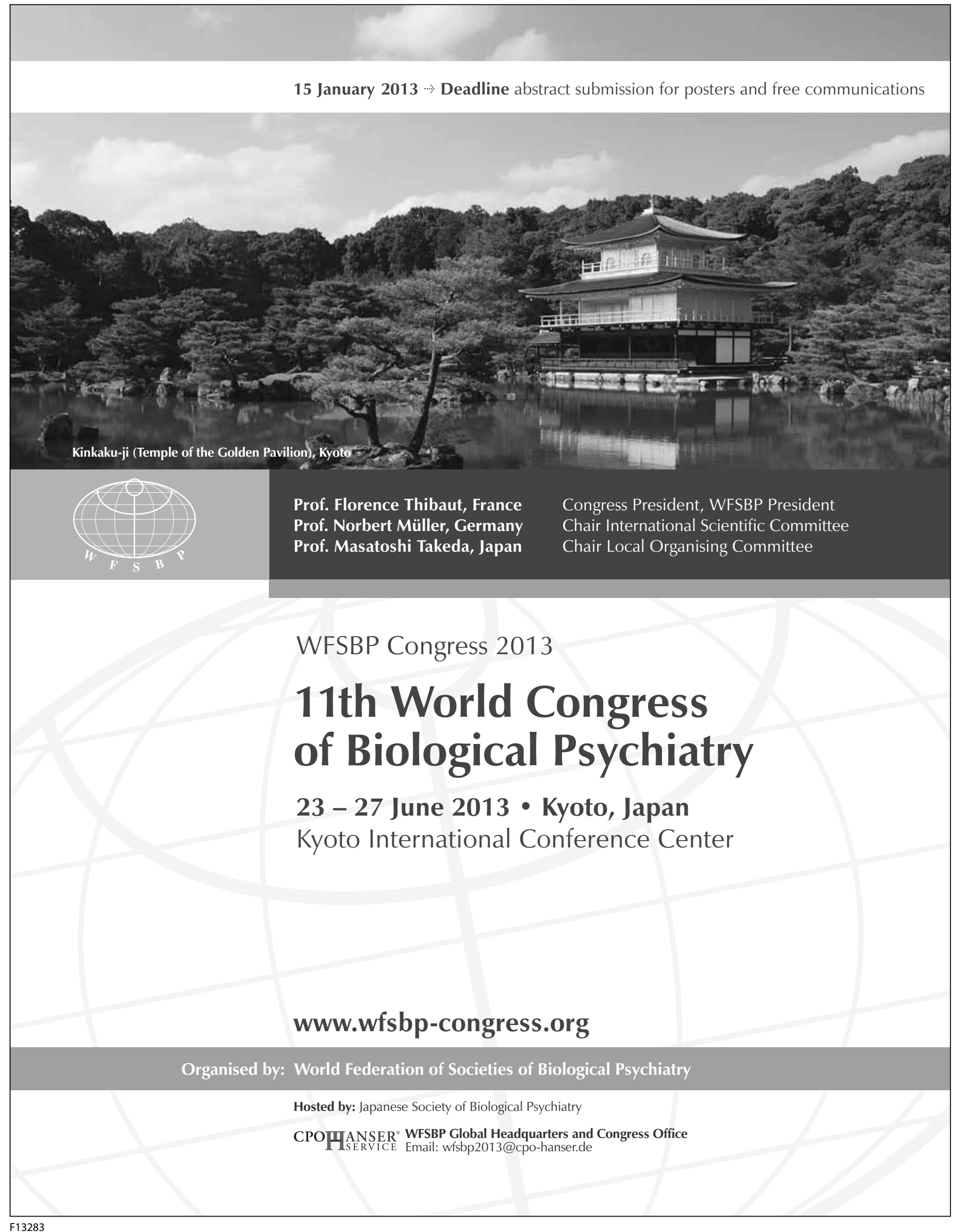




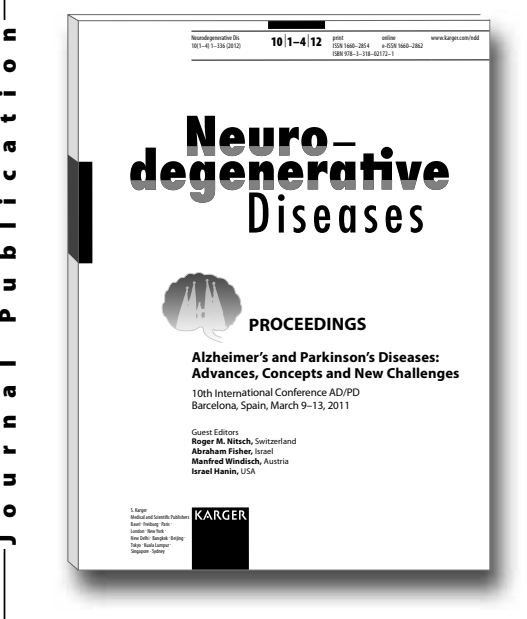

Selected Contents

\section{Nobel Lecture}

Intracellular Protein Degradation: From a Vague Idea through the Lysosome and the UbiquitinProteasome System and onto Human Diseases and Drug Targeting: Ciechanover, $\boldsymbol{A}$.

\section{Biology of Neurodegeneration}

Wnt-5a Is a Synaptogenic Factor with Neuroprotective Properties against $A \beta$ Toxicity: Varela-Nallar L. et al.

Intraneuronal A $\beta$ Accumulation, Amyloid Plaques, and Synapse Pathology in Alzheimer's Disease: Capetillo-Zarate et al.

Tau Overexpression Results in Its Secretion via Membrane Vesicles: Simón, D. et al.

Microglial Activation in Neuroinflammation: Implications for the Etiology of Neurodegeneration: Kaneko, Y.S.et al.

Retromers in Alzheimer's Disease: Siegenthaler, B.M.; Rajendran, $L$.

Clinical Studies and Observations

Effects of Exercise and B Vitamins on Homocysteine and Glutathione in Parkinson's Disease: A Randomized Trial: DiFrancisco-Donoghue, J. et al.

Evaluation of the Performance of Novel A $\beta$ Isoforms as Theragnostic Markers in Alzheimer's Disease: From the Cell to the Patient: Portelius, E. et al.

\section{Alzheimer's and Parkinson's Diseases: Advances, Concepts and New Challenges \\ Proceedings}

\author{
Editors \\ Roger M. Nitsch \\ Abraham Fisher \\ Manfred Windisch \\ Israel Hanin
}

Software Tool for Improved Prediction of Alzheimer's Disease: Soininen, $\boldsymbol{H}$. et al.

Cortical Brain Biopsy in Long-Term Prognostication of 468 Patients with Possible Normal Pressure Hydrocephalus: Leinonen, $\boldsymbol{V}$. et al. Towards Defining a Rigidity-Associated Pathogenic Pathway in Idiopathic Parkinsonism: Dobbs, R.J. et al.

Imaging, Biomarkers, Genetics, and

Diagnostic Markers

Cognitive Function in Health and Disease: The Role of Epigenetic Mechanisms: Mungenast, A.E.; Tsai, L.-H.

Pin1 Contribution to Alzheimer's Disease: Transcriptional and Epigenetic Mechanisms in Patients with Late-Onset Alzheimer's Disease: Arosio, B.et al.

Activation of the Unfolded Protein Response Is an Early Event in Alzheimer's and Parkinson's Disease: Hoozemans, J.J.M. et al.

Targeting Skp1, an Ubiquitin E3 Ligase Component Found Decreased in Sporadic Parkinson's Disease: Mandel, S.A. et al.

A Pilot Study Examining Associations between DYRK1A and $\alpha$-Synuclein Dementias: Jones, E.L. et al.

Structural MRI in Normal Aging and Alzheimer's Disease: White and Black Spots: Cavalieri, M. et al.
Immunization and Innate Immunity Innate Immunity and the Etiology of Late-Onset Alzheimer's Disease: Eikelenboom, P. et al.

Curcumins Promote Monocytic Gene Expression Related to $\beta$-Amyloid and Superoxide Dismutase Clearance: Cashman, J.R. et al.

Prion Proteins, Statins, Cholestero

$\alpha$-Secretase-Derived Cleavage of Cellular Prion Yields Biologically Active Catabolites with Distinct Functions: Guillot-Sestier, M.-V.; Checler, F.

Cellular Prion Protein Mediates Toxic Signaling of Amyloid Beta: Resenberger, U.K.; Winklhofer, K.F.; Tatzelt, J.

Dual Effects of Statins on A $\beta$ Metabolism: Upregulation of the Degradation of APP-CTF and $\mathrm{A} \beta$ Clearance: Sato, $\boldsymbol{N}$. et al.

Cerebrovascular Lesions and

Primary Neurodegenerative Diseases

Plasma $\beta$-Amyloid Levels in Cerebral Amyloid Angiopathy-Associated Hemorrhagic Stroke: Hernandez-Guillamon, $M$. et al.

Insights into Caspase-Mediated Apoptotic Pathways Induced by Amyloid- $\beta$ in Cerebral Microvascular Endothelial Cells: Fossati, S. et al.

Neuroinflammation and Blood-Brain Barrier Changes in Capillary Amyloid Angiopathy: Carrano, A. et al.

For full table of contents please log on to $\mathbf{w} w \mathbf{w} . \mathbf{k a r g e r . c o m} / \mathbf{n d d}$
Alzheimer's and Parkinson's Diseases: Advances, Concepts and New Challenges 10th International Conference AD/PD, Barcelona March 2011: Proceedings

Editors: Nitsch, R.M. (Switzerland); Fisher, A. (Israel); Windisch, M. (Austria); Hanin, I. (USA) 336 p., 105 fig., 6 in color, 33 tab., soft cover, 2012 CHF 86.- / EUR 72.- / USD 101.00

Prices subject to change

EUR price for Germany, USD price for USA only

ISBN 978-3-318-02172-1 e-ISBN 978-3-318-02173-8

Special Topic Issue: Neurodegenerative Diseases Vol. 10, No. 1-4 (2012) Included in subscription

\section{$\rightarrow$ Please send: __ copy/ies}

Postage and handling free with prepayment

E

Please charge to my credit card

- $\square$ American Express $\square$ Diners

ᄂ $\square$ MasterCard $\square$ Visa

Card No.

Exp. date:

- CVV/CVC

( 3 digits in the signature field on the back of Visa and MasterCard)

$\square$ Check enclosed $\quad \square$ Please bill me

Orders may be placed with any bookshop, subscription agency, directly with the publisher or through a Karger distributor.
Fax: +41613061234

S. Karger AG, P.O. Box, CH-4009 Basel (Switzerland)

E-Mail orders@karger.ch, www.karger.com

Name/Address: 


\section{A new vision to understanding medicine}

\section{Handbook of Clinical Gender Medicine}

Editors: Karin Schenck-Gustafsson (Stockholm), Paula R. Decola, Donald W. Pfaff (New York, N.Y.), David S.Pisetsky (Durham N.C.)

In well-referenced chapters, experts cogently and concisely explain how the incorporation of gender issues into research can affect the medical understanding and treatment of heart disease, osteoporosis, arthritis, pain as well as malaria among other conditions.

This intriguing and unique medical textbook provides readers with a valuable new perspective on how to incorporate gender issues into the different branches of medicine.



\section{KARGER BOOKS ON MEDICAL PHILOSOPHY}

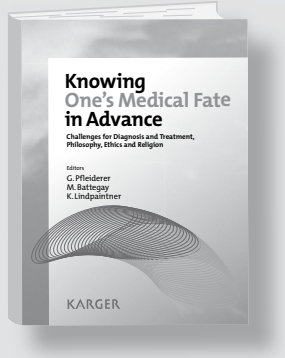

\section{Knowing One's Medical Fate in Advance}

Challenges for Diagnosis and Treatment, Philosophy, Ethics and Religion

Editors: G. Pfleiderer, M. Battegay, K. Lindpainter

$\mathrm{VI}+122$ p., 4 fig., 2 in color, hard cover, 2012 CHF 59. - / EUR 49.- / USD 69.00 ISBN 978-3-8055-9649-7
The certainty and uncertainty of one's fate are discussed from both methodological and epidemiological perspectives, using examples of diseases for which treatment and prognosis have dramatically changed. Despite profound insights into the human genome, personalized genetically tailored medicine still lies in the future. Religious, spiritual and philosophical dimensions are discussed, as are the ways in which they may help people cope with these new insights into their future, e.g. the promise of an afterlife.

This publication aims to bridge the different fields dealing with this area by addressing the challenges faced and encouraging dialogue. It will be of interest to all readers who deal with ethical problems of prognosis, particularly in medicine, as well as to theologians and sociologists.



\section{GenEthics and Religion}

Editors: G. Pfleiderer, G. Brahier K. Lindpaintner

$\mathrm{VI}+154 \mathrm{p}$., hard cover, 2010

CHF 29.- / EUR 24.- / USD 34.00

ISBN 978-3-8055-8973-4

Prices subject to change;

EUR price for Germany, USD price for USA only

Based on the symposium 'GenEthics and Religion' (Basel, Switzerland, May 2008), this volume examines the role religion can play in establishing ethical guidelines to protect human life in the face of rapid advances in biology and gene technology. It does so with contributions by philosophers, theologians, human geneticists, and several bioethicists representing the Christian, Jewish, Islamic and Buddhist perspectives. The essays illustrating a diversity of views and expressing the problems and self-critical reflectiveness of religious ethicists are brought up to date and discuss the importance of religious ethics in society's discourse on gene technology. 


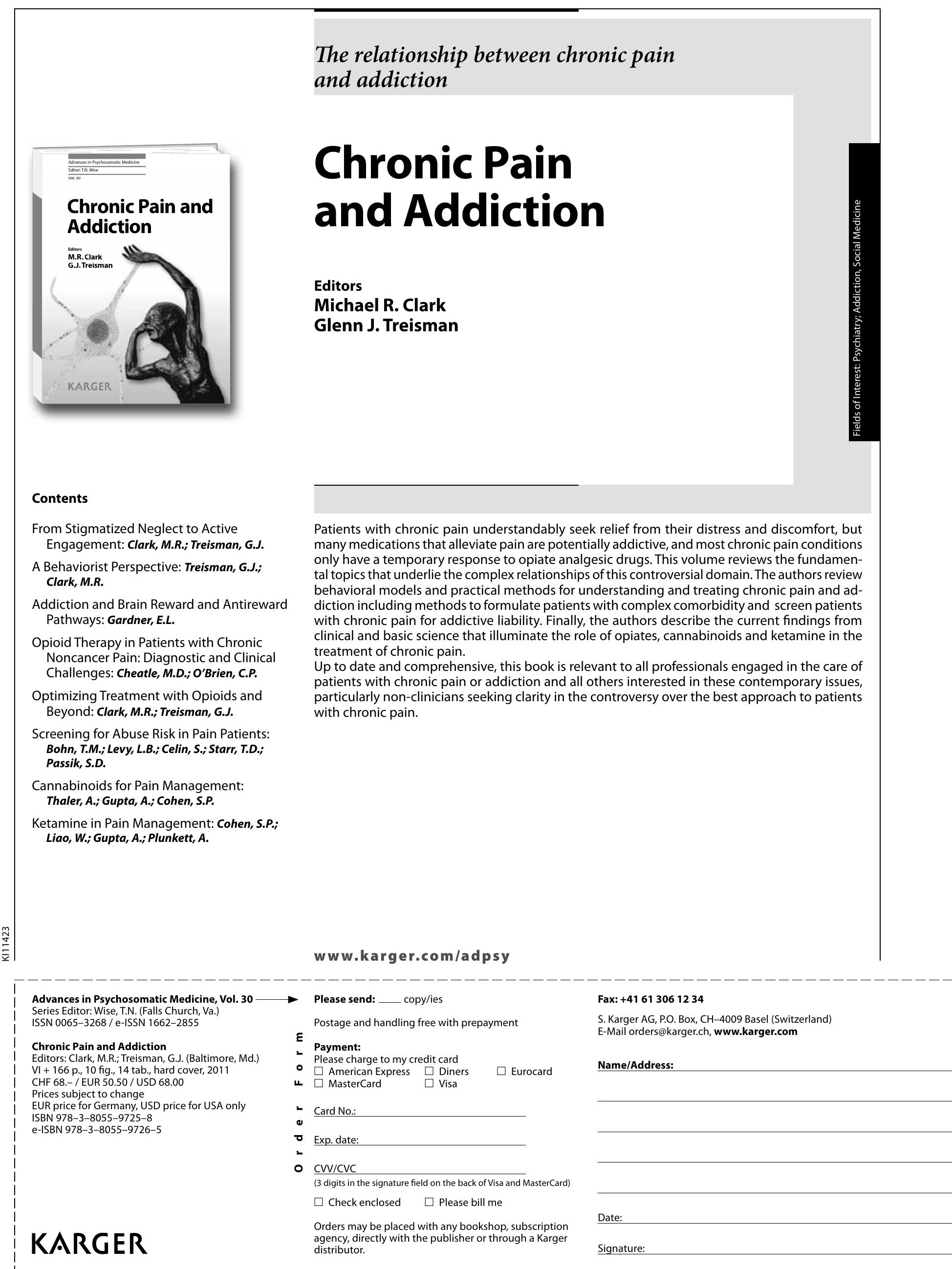




\title{
A unique Journal devoted to the study of cognitive dysfunction in preclinical and clinical studies
}

Dementia

\author{
Editor-in-Chief \\ V. Chan-Palay, \\ New York, N.Y.
}

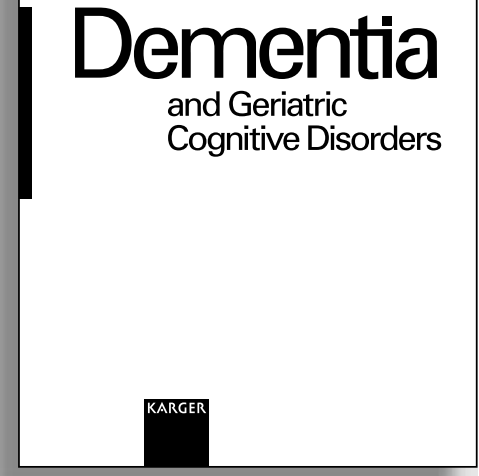

More information at

\section{www.karger.com/dem}

- Pay-per-View and Subscriber Access to Full Text

- Full Table of Contents

- Full Editorial Board

- Free Abstracts and Selected Articles

- Online Sample Issue

- Submission/Guidelines for Authors

- Subscription Details

- Free Alert Service

- Online Library Recommendation

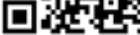

Dementia and Geriatric Cognitive Disorders 2013: Volumes 35,36

6 issues per volume

Language: English

ISSN 1420-8008 (print)

ISSN 1421-9824 (online)

\section{Selected contributions}

- Review of Cerebral Microangiopathy and Alzheimer's Disease: Relation between

White Matter Hyperintensities and Microbleeds: Hommet, C. et al.

- Executive Function and Activities of Daily Living in Alzheimer's Disease:

A Correlational Meta-Analysis: Martyr, A. et al.

- Longitudinal Changes in Cognition in Parkinson's Disease with and without

Dementia: Johnson, D.K., et.al

- Linkage Analysis of Autopsy-Confirmed Familial Alzheimer Disease Supports an

Alzheimer Disease Locus in 8q24: Sillén, A., et.al

- Changes in Vascular Risk Factors from Midlife to Late Life and White Matter

Lesions: A 20-Year Follow-Up Study: Vuorinen, M., et.al

- The Montreal Cognitive Assessment and the Mini-Mental State Examination as

Screening Instruments for Cognitive Impairment: Item Analyses and Threshold

Scores: Damian, A.M., et.al

- Apolipoprotein E 44 Prevalence in Alzheimer's Disease Patients Varies across

Global Populations: A Systematic Literature Review and Meta-Analysis:

Crean, S., et.al

- Nonpharmacological Therapies in Alzheimer's Disease: A Systematic Review of

Efficacy: Olazarán, J., et.al

- Prevalence of Dementia in Elderly Living in Two Cities of Central Africa: The EDAC

Survey: Guerchet, M., et.al
As a unique forum devoted exclusively to the study of cognitive dysfunction, Dementia and Geriatric Cognitive Disorders concentrates on Alzheimer's and Parkinson's disease, Huntington's chorea and other neurodegenerative diseases. The journal draws from diverse related research disciplines such as psychogeriatrics, neuropsychology, clinical neurology, morphology, physiology, genetic molecular biology, pathology, biochemistry, immunology, pharmacology and pharmaceutics. Strong emphasis is placed on the publication of research findings from animal studies which are complemented by clinical and therapeutic experience to give an overall appreciation of the field. 


\section{Neuropsychobiology}

Original Papers

1 The CLOCK C3111T Polymorphism Is Associated with Reward Dependence in Healthy Japanese Subjects

Tsuchimine, S.; Yasui-Furukori, N.; Kaneda, A.; Kaneko, S. (Hirosaki)

6 Gender-Specific Effects of Brain-Derived Neurotrophic Factor Val66Met Polymorphism and Childhood Maltreatment on Anxiety

Min, J.-A.; Lee, H.-J. (Seoul); Lee, S.-H. (Goyang); Park, Y.-M. (Seoul); Kang, S.-G. (Daegu); Chae, J.-H. (Seoul)

14 Assessment of Cognitive Impairments and Seizure Characteristics in Electroconvulsive Therapy with and without Sodium Valproate in Manic Patients Haghighi, M. (Hamadan); Bajoghli, H. (Tehran); Bigdelou, G.; Jahangard, L. (Hamadan); Holsboer-Trachsler, E.; Brand, S. (Basel)

25 Serum Neurotrophin Concentrations in Polish Adolescent Girls with Anorexia Nervosa

Dmitrzak-Weglarz, M.; Skibinska, M.; Slopien, A.; Tyszkiewicz, M.; Pawlak, J.; Maciukiewicz, M.; Zaremba, D.; Rajewski, A.; Hauser, J. (Poznan)

33 Metabolic and Glutathione Redox Markers Associated with Brain-Derived Neurotrophic Factor in Depressed African Men and Women: Evidence for Counterregulation?

Harvey, B.H. (Potchefstroom); Hamer, M. (Potchefstroom/London); Louw, R.; van der Westhuizen, F.H.; Malan, L. (Potchefstroom)

41 TPH1, MAOA, Serotonin Receptor 2A and 2C Genes in Citalopram Response: Possible Effect in Melancholic and Psychotic Depression

Arias, B. (Barcelona/Madrid); Fabbri, C. (Bologna); Gressier, F. (Paris); Serretti, A. (Bologna); Mitjans, M. (Barcelona); Gastó, C.; Catalán, R. (Barcelona/Madrid); De Ronchi, D. (Bologna); Fañanás, L. (Barcelona/Madrid)

48 Neural Substrates of Amphetamine-Induced Behavioral Sensitization: Unconditioned (Zero Context) and Conditioned (Switch versus Same Context) Components in c-fos Overexpression

Wang, Y.-C. (New Taipei City); Yeh, Y.-C. (Taipei); Wang, C.-C. (New Taipei City); Hsiao, S. (Minxiong); Lee, C.-C. (Taipei); Huang, A.C.W. (Jiaoxi) 